\title{
Front Matter: Volume 11746
}

, "Front Matter: Volume 11746," Proc. SPIE 11746, Artificial Intelligence and Machine Learning for Multi-Domain Operations Applications III, 1174601 (5 May 2021); doi: 10.1117/12.2598645

SPIE. Event: SPIE Defense + Commercial Sensing, 2021, Online Only 


\title{
PROCEEDINGSOF SPIE
}

\section{Artific ial Intelligence and Machine Leaming for Multi-Domain Operations Applic ations III}

\author{
Tien Pham \\ Latasha Solomon \\ Editors
}

\section{2-16 April 2021}

Online Only, United States

Sponsored and Published by

SPIE 
The papers in this volume were part of the technical conference cited on the cover and title page. Papers were selected and subject to review by the editors and conference program committee. Some conference presentations may not be available for publication. Additional papers and presentation recordings may be a vaila ble online in the SPIE Digital Libra ry at SPIEDigita lLibrary.org.

The papers reflect the work and thoughts of the authors and a re published herein as submitted. The publisher is not responsible for the valid ity of the information or for any outc omes resulting from reliance thereon.

Please use the following format to cite material from these proceedings: Author(s), "Title of Paper," in Artific ial Intelligence and Machine Leaming for Multi-Doma in Operations Applications III, edited by Tien Pham, Latasha Solomon, Proc. of SPIE 11746, Seven-digit Article CID Number (DD/MM/YYYY); (DOI URL).

ISSN: 0277-786X

ISSN: 1996-756X (electronic)

ISBN: 9781510643291

ISBN: 9781510643307 (electronic)

Published by

SPIE

P.O. Box 10, Bellingham, Wa shington 98227-0010 USA

Telephone +1 3606763290 (Pacific Time)

SPIE.org

Copyright @ 2021 Society of Photo-Optic al Instrumentation Engineers (SPIE).

Copying of material in this book for intemal or personal use, or for the intemal or personal use of specific clients, beyond the fair use provisions granted by the U.S. Copyright Law is authorized by SPIE subject to payment of fees. To obta in permission to use and sha re a ricles in this volume, visit Copyright Clearance Center at copyright.com. Other copying for republication, resale, a dvertising or promotion, or any form of systematic or multiple reproduction of any material in this book is prohibited except with pemission in writing from the publisher.

Printed in the United States of America by Curran Associates, Inc., under license from SPIE.

Publication of record for individual papers is online in the SPIE Digital Library.

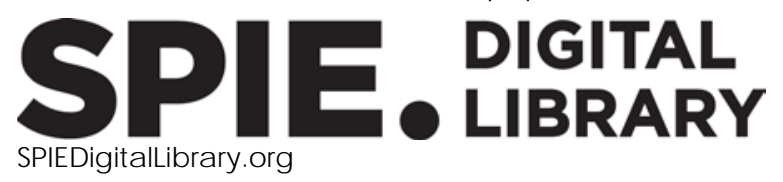

\footnotetext{
Paper Numbering: A unique c itation identifier (CID) number is a ssigned to each artic le in the Proceedings of SPIE at the time of public ation. Utilization of CIDs allows artic les to be fully citable as soon as they are published online, and connects the same identifier to all online and print versions of the publication. SPIE uses a seven-digit CID article numbering system structured as follows: - The first five digits correspond to the SPIE volume number.

- The last two digits indic ate public ation order within the volume using a Base 36 numbering system employing both numerals and letters. These two-number sets start with $00,01,02,03,04$, 05, 06, 07, 08, 09, 0A, 0B ... 0Z, followed by 10-1Z, 20-2Z, etc. The CID Number appears on each page of the manuscript.
} 


\section{Contents}

\section{MULTI-DOMAIN OPERATIONS: CONCEPISAND FUTURE TRENDS}

$1174606 \quad$ Artificial intelligence and machine leaming: a perspective on integrated systems opportunities and challenges for multi-domain operations [11746-2]

1174607 Improving the performance of Al models in tactical environments using a hybrid cloud architecture (Invited Paper) [11746-3]

1174608 Context-sensitive, distributed, multi-domain adaptive option generation [11746-4]

1174609 Secure and trustworthy machine leaming/artificial intelligence for multi-domain operations (Invited Paper) [11746-99]

IEARNING AND REASONING WTH SMALDATA SAMPLES, DIRTY DATA, HIGH CWTIER, AND DECEPIION

11746 OB Decision making with uncertainty using the LRM method: MATAB versus J ava [11746-5]

11746 OE Neural network-based band selection on hyperspectral imagery [11746-8]

11746 OF Creating a semantic hierarchy of SUN database object labels using WordNet [11746-9]

\section{AI-ENABIFD STUATION AWARENESS AND CONTIEXTAWARE DECISION MAKING}

$11746 \mathrm{OH} \quad$ Unsupenised leaming for target tracking and background subtraction in satellite imagery [11746-10]

$11746 \mathrm{0}$ ol A modular system for behaviour analytics from airbome full-motion video [11746-11]

11746 0] Empirical game-theoretic methods to minimize regret against specific opponents [11746-12]

11746 OK Unsupenised multi-view object proposal ranking [11746-13]

$11746 \mathrm{OL} \quad$ Optimizing the efficiency of collective decision making in groups [11746-14] 
NOVELAIMLRAMEWORKAND ARCHITECTURES

1174600 The joumey to collaborative Al at the tactical edge (CATE) [11746-17]

$117460 Q \quad$ What's data got to do with it? [11746-19]

ADVERSARIAL MACHINE LEARNING AND SECURTY

11746 0T Emergent reinforcement leaming behaviors through novel testing conditions [11746-22]

11746 OV Machine leaming raw network trafic detection [11746-24]

11746 OW Deep leaming approach for attack detection in controllerarea networks [11746-25]

11746 0X Investigation of a differential cryptanalysis inspired approach forTrojan Al detection [11746-26]

11746 OY Towards Botnet hazard analysis with generative adversarial networks for threat detec tion [11746-27]

11746 OZ TextCycleGAN: cyclical-generative adversarial networks for image captioning [11746-28]

1174610 Using options to improve robustness of imitation leaming againstadversarial attacks [11746-29]

1174611 On the benefits of robust models in modulation recognition [11746-30]

1174612 Cooperative monitoring for detecting adversarial communication [11746-31]

\section{HUMAN AGENTTEAMING}

1174613 Robust uncertainty representation in human-Al collaboration [11746-32]

$1174614 \quad$ Human data collection for machine leaming and artificial intelligence aid development for multi-domain operations [11746-33]

1174615 Battlespace: using Al to understand friendly vs. hostile decision dynamics in MDO [11746-34]

1174616 Analyzing a human-in-the-loop's decisions for the detection of data poisoning [11746-35] 
NOVELAIMLMODES, ALGORTHMS AND APPUCATIONS

1174617 Deep leaming restoration of signals with additive and convolution noise [11746-36]

1174618 Multi-agent reinforcement leaming for convex optimization [11746-37]

1174619 Statistical sparsity-based leaming for ulta-wideband radar signal reconstruc tion [11746-38]

AUIONOMOUS MANEUVER IN COMPLEX ENVIRONMENT

11746 1B A Bayesian spatio-temporal airc raft route predic tive algonithm with applications to military operations [11746-40]

11746 1C Machine leaming for longwave infrared image enhancement to improve maneuverability hazard detection [11746-41]

11746 1D Risk-aware autonomous navigation [11746-42]

11746 IF Effects of perturbed depth sensors in autonomous ground vehic les [11746-44]

$117461 \mathrm{H} \quad$ Low latency adversarial threat avoidance, navigation in 3D point cloud environment via multagent reinforcement leaming in a comespondence 2D floomlan [11746-46]

11746 1l Evaluation of multimodal semantic segmentation using RG B-D data [11746-47]

EXPLAINABIE AND AI-ENABIFD ANALYTICS

11746 1] Decisions, graphs, and artificial reasoning for uncertainty of information [11746-48]

$117461 \mathrm{~L} \quad$ Generating explanations for answer set programming applications [11746-50]

11746 1M Augmenting saliency maps with uncertainty [11746-51]

FEERATED/ DISTRIBUIED AI/ML

1174610 Embedding dynamic knowledge graphs based on observational ontologies in semantic vector spaces [11746-52]

$117461 Q \quad$ Energy effic ient 'in memory' computing to enable decentralised senvice workfiow composition in support of multi-domain operations [11746-54] 


\section{COALTION AND JOINTOPERATIONS}

$117461 T \quad$ Leaming-aided SDC control in mobile ad hoc networks [11746-57]

11746 1W Reinforcement and transfer leaming for distributed analytics in fragmented software defined coalitions [11746-60]

$117461 \mathrm{X}$ Coalition situational understanding via explainable neuro-symbolic reasoning and leaming [11746-61]

$117461 Y$ From social networks to negative ties: refining analysis for conflict and adversanial interaction [11746-62]

1174620 3D simulation and scenario for Al research in multi-domain and coalition operations [11746-64]

MODEUNG AND SMULATION

1174622 Autonomous network cyber offence strategy through deep reinforcement leaming [11746-66]

1174623 Computational modeling approaches to characterize risk and achieve safe, effective, and trusted designs in the development of artificial intelligence and autonomous closed-loop medical systems [11746-67]

$1174624 \quad$ Generating genetic engineening linked indicator datasets for machine leaming classifier training in biosec unity [11746-68]

1174625 Expenimentation for optimization of heterogeneous drone swam configurations: tenain and distribution [11746-69]

1174626 Scalability in modeling and simulation systems for multi-agent, Al, and machine leaming applications [11746-70]

\section{ARIIRC IALINIEUGENCE/MACHINE LEARNING AND UNMANNED SYSTEMS: JOINTSESSION WTH} 11746 AND 11758

1174628 Using Al-ML to develop energy and exergy flow characterizations for multi-domain operations [11746-72]

1174629 Differential morphological profile neural network for maneuverability hazard detection in unmanned aenial system imagery [11746-73]

11746 2A Validation of object detection in UAV-based images using synthetic data [11746-74]

11746 2B Performance evaluation of multimodal deep leaming: object identification using UAV dataset [11746-75] 
$117462 \mathrm{C}$ Robust machine leaming algonithms for image segmentation in biphasic ceramics [11746-76]

$117462 \mathrm{E} \quad$ Incremental leaming-based jammer classification [11746-78]

$117462 \mathrm{H}$ Towards an explainable Al adjunct to deep network obstacle detection for multisensor vehicle maneuverability assessment [11746-81]

11746 2] Explainable Al for medical imaging: explaining pneumothorax diagnoses with Bayesian teaching [11746-83]

$117462 \mathrm{~K} \quad$ Survey of recent multi-agent reinforcement leaming algonithms utilizing centra lized training [11746-84]

$117462 \mathrm{~L} \quad$ Remote sensing: leveraging cloud loTand Al/ML senvices [11746-85]

11746 2N Machine leaming for source classification utilizing infrasound data [11746-87]

1174620 A two-level strategy based on evolutionary algonithm to solve the inter-domain path computation under node-defined domain uniqueness constraint [11746-88]

117462 Recent advances in adversarial machine leaming: status, challenges and perspectives [11746-90]

$117462 R \quad$ Identifying novel vessel classes with OOD methods [11746-91]

1174625 Deep leaming at the edge: automatic modulation classification on real world signals [11746-92]

$117462 T \quad$ SAGE supporting operations research inspired algonithms [11746-93]

$117462 \mathrm{U}$ Soldier-led Adaptation of Autonomous Agents (SA3) [11746-94]

$117462 \mathrm{~V} \quad$ Accumulating confidence for deep neural network object detections and semantic segmentations in sequential UAS imagery through spatiotemporal feature comespondences generated from SiM techniques [11746-95]

11746 2W Rigorous evaluation of vector-associated model performance (REVAMP) [11746-96]

$117462 X \quad$ Semantic lifting of integrated messages (SUM) [11746-97] 
Proc. of SPIE Vol. 11746 1174601-8

Downloaded From: https://www.spiedigitallibrary.org/conference-proceedings-of-spie on 26 Apr 2023
Terms of Use: https://www.spiedigitallibrary.org/terms-of-use

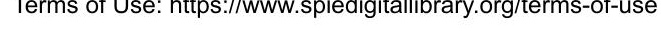

